\title{
一特集 悪性高血圧症
}

\section{悪 性 高 血 圧 ——成 \\ 因}

尾 前 照 雄*

\section{はじめに}

Bright 氏病を病理学的に検討し, 動脈硬化性 疾患 (Arteriosklerotische Erkrankung) を分離 した Volhard と Fahr1) (1914年) は良性高血 圧 (blande, gutartige Hypertonie) に対比して maligne Nephrosklerose (Kombinatiosform) を 区別した。そ後，臨床的立場から Keith ら （1928年）は，進行性の経過をたどり予後がき わめて悪く，眼底に特徵的な所見を有し，しか も腎炎と異なる高血圧を 1 つの症候群としてと ら光，これに悪性高血压症候群 (syndrome of malignant hypertension) といら名称を与元た.

扮伃まかには，悪性高血圧の形態学的表現型 が悪性腎硬化 $\left(\mathrm{Fahr}^{47)}\right)$ と考えられる ${ }^{3) 4)}$ 。 そ の組織学的特徵は，一般に全身ことに腎の細動 脈怙よび小動脈にみられる血管壊死 (fibrinoid arteriolar necrosis) と細胞性内膜增殖 (cellular intimal hyperplasia) とされている5). しかし， 良性高血圧にも血管壊死がみられるといら報告

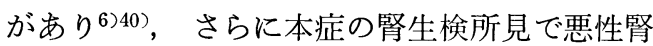
硬化を呈しない場合があり，本症に特異的な組 織所見はないとする意見もある77。 これは，本 症が高血圧症の進展という時間的要素を持った 臨床概念であるのに対し, 悪性腎硬化が本症の 終末像から導かれた病理学的 entity であるこ とを考えるならば理解しらることである。

本症に特徵的とされる上述の病変の histogenesis に関する多くの病理学的研究は, 悪性高 血圧の成因論の大きな部分を占めているが558),

* 九州大学医学部第二内科

\section{江 藤 㸝 尚}

その成因として血管内圧の上昇, 中毒性, 代謝 性あるいは体液性因子, 抗原抗体反応, 自己免 疫現象などの機転が考えられている

その成因を論ずる前に，先ず悪性高血圧の臨 休的定義についてふれなければならない，次い で，その成因と病態生理を考察することにす る.

\section{I. 悪性高血圧の定義と特徵的な所見}

覀性高血圧は, (1)高度の高血圧, 特に拡張期 圧の著しい上昇（ほとんど例外なく $120 \mathrm{mmHg}$ 以上)，(2) 経過が速かであること，(3) 多くは乳 頭浮腫を伴なら高度の眼底所見を有すること， (4)腎機能障害の進行が速やかで, 多くは尿毒症 で死亡するなどの特徵を有する症候群と定義さ れている ${ }^{7) 10)}$ ，最初から悪性高血圧として発症 する少数例を除くと，大部分は基礎疾患として 本態性あるいは 2 次性高血圧が存在する。２次 性高血圧のなかでは, 系球体腎炎, 慢性腎孟腎 炎，のう胞腎，腎血管性高血圧，放射線による 腎障害 (radiation nephritis) などの腎疾患, 褐 色細胞腫, Cushing 症候群, 膠原病 (SLE, 結 節性動脈周囲炎，汎発性強皮症など)，妊娠中 毒症などの際みられることが知られており ${ }^{11)}$ ， 最近では経口避妊薬によって扣こる場合も知ら れている ${ }^{12)}$. Conn 症候群は，はじめ悪性高血 圧の症状を示すものはないとされていたが13), 現在までに幾つかの報告がある14) 16).

このように, 大動脈縮窄症以外のほぼすべて の拡張期性高血圧に，悪性高血圧がみられるこ とから，本症は 1 つの疾患単位というょり，高 血圧症の 1 つの状態, つまり症候群であること 
が理解される。しかながら，個々の症例につ いてみると，上述の基準の全てが満される場合 のみとは限らない10). したがって，これらの基 準のぞれが必要最小限の条件 (pathognomonic) であるかを検討することが必要と考えられる。

\section{1. 高血圧}

Keith ら 2)は80例の悪性高血压において, 収縮 期および拡張期圧はそれぞれ 220〜 $280 \mathrm{mmHg}$, 120〜190mmHg であったと報告した。 Page ${ }^{17) ，}$ Ellis ${ }^{18)}$ らは拡張期血圧が $130 \mathrm{mmHg}$ 以下のこ とはないとし, 著者ら ${ }^{10)}$ の経験でも, 本症の生 存例における血圧の平均值は収縮期 $230 \mathrm{mmHg}$, 昖張期血生 $125 \mathrm{mmHg}$ であった。 Schottstaedt と Sokolow の報告19)では, 経過中に測定した 血圧の最低值の平均は, 収縮期 $190 \mathrm{mmHg}$, 拡 張期血圧 $117 \mathrm{mmHg}$ で, 経過中に拡張期圧が急 に下降することがあるが，その際でもほとんど の場合 $120 \mathrm{mmHg}$ のレベルに止まるとしてい る.これに反し Kincaid-Smith $ら^{6)}$ は, 良性と 悪性高血圧の間に, 血圧のレベルの差が認めら れなかったとし，血圧の高さが両者を分ける基 準にはならないことを主張している。しかしな がら, 種々の基礎疾患にみられる共通な所見と して, 高度の高血圧をもっとも重要な基準とみ なす者が多(、7)1120).

\section{2. 眼底 所見}

Keith $ら^{21)}$ の本態性高血圧の子後についての 歴史的な報告以来, “neuro-retinopathy” の出 現は一般にもっとも確実な本症の診断基準とさ れている. Ellis ${ }^{18)}$ は乳頭浮腫が存しないと本 症の診断はつけないと述べている。 Pickering11) は“neuro-retinopathy” が良性高血圧から本症 を区別するもっとも特徵的な所見と考光,

Fishberg4) も本症のほとんどの症例に “neuroretinopathy” があるとしている. Gifford ${ }^{22)}$ は “"neuro-retinopathy”とは乳頭浮腫の存在を意 味すると述べ，これが本症に pathognomonic であると考光ている。

Keith ら ${ }^{23)}$ は, 悪性高血圧の自然の経過中に 乳頭浮腫が消失する症例を報告しているが, Goldring と Chasis ${ }^{24)}$ は形態的に確診のついた 本症68例中乳頭浮腫を呈しなかったものが16例
(23\%) あったと報告している. Brust ${ }^{20)}$ も，悪 性高血圧あるいは accelerated hypertension の 基準として，乳頭浮腫を必須のものとはしてい ない. このように, 乳頭浮腫が診断基準とし て, 十分条件であることについての異論はない が, 必要条件としての評価は必ずしも一致して いない。

\section{3. 腎 不 全}

Milliez $ら^{7)}$ は悪性高血圧の死因の $72 \%$, 心不全の合併例をも含めた尿毒症が占め, 残り の $28 \%$ が脳卒中死であったことから，進行性の 腎障害を本症の必須の条件之考觉た。しかし, KW IV 度の眼底所見を示す高血圧者において， 必ずしも高度の腎障害があるとは限らないと いら報告もある。すなわち Schottstaedt と Sokolow ${ }^{19)}$ はそのよらな 104 例中 37 例に打い て, 腎機能がほ潼満足すべき状態のものがあっ たといら。これらの症例は高度の腎障害を示す ものより予後がやや良好であったが，その後腎 障害が急速に進行し，しばしば尿毒症で死亡す ると述べている，Perera25) も同様に，進行性 の腎障害を診断の必須条件としている。褐色細 胞腫による悪性高血圧をのぞけば"1)，速かで進 行性の経過をたどり, 腎障害がこれと平行して 増悪することは, 本症候群の特徵的な病像とさ れている。

以上述べてきた診断基準にもとずいづいて, 悪性高血圧の成因にもっとも深いかかわりをも つと考兄られる高血圧，腎障害と腎に由来する 体液性あるいは代謝性因子を中心に，その成因 を論ずることにする。最後にこれらのと腎の形 態学的所見および血管障害との関係について触 れてみた。

\section{II. 悪性高血圧の成因}

\section{1，高血圧の意義}

Pickering ${ }^{11)}$ は良性高血圧と悪性高血圧の差 は, 高血圧の重症度にもとづくとし, 本症の成 因を一元的に説明しょうとする立場をとってい る。その根拠として，（1）良性期よりも悪性期 の血圧がょり高い傾向にある，(2）基礎疾患の いかんにかかわらず, 高血圧の程度が強ければ 
悪性高血压が出現する，（3）肺動脈高血圧でも 悪性高血圧と同様な血管壊死が生ずる。（4）良 性高血圧から悪性高血圧へ移行する前に, 必ず より高度の血圧上昇が観察される，(5) 降圧療 法により悪性高血圧の予後が著しく改善し, 血 管病変も改善するなどの理由をあげている.

高血圧者の腎生検材料について, 拡張期血圧 と腎の動脈病変の程度との関係を検討した Heptinstall26) は，血管壊死は拡張期圧が 150 $\mathrm{mmHg}$ になると出現し，血圧の上昇につれて その頻度が増すことを示し, Pickering の説を 支持する成績を報告している.

1934年に Goldblatt ら ${ }^{27)}$ は, 犬に腎動脈狭窄 を施こすことにより実験的に高血圧を作製する ことに成功したが，腎の排泄障害をきたす程 度に両側の腎動脈を強く狭窄すれば，血管壊死 (necrosis of arterioles) 拉よび出血が生じ, 悪 性高血圧 (malignant phase of hypertension) 実験的に作製できることを見出した ${ }^{28)}$. この実 験結果はから, Goldblatt は悪性高血圧の成因 に，血圧の上昇 (mechanical factor) のみなら ず腎の排泄機能障害およびこれに関係した humoral factor の関与が必要であると考えた ${ }^{28)}$.

他方, Wilson と Pickering ${ }^{29)}$ も同年の1938年 に, 同様の方法によって家鬼に fibrinoid necrosis を作ることに成功し，血管病変の程度と 重症度は高血圧の持続とその程度に関係するこ

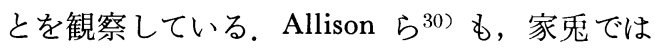
拡張期血圧が $140 \mathrm{mmHg}$ を超えると, fibrinoid necrosis がみられるとし, 挔張期血圧のレベルと 悪性高血圧が密接な関係にあることを示した。 ついで, Wilson と Byrom ${ }^{31)}$ は対側腎に操作を 加えることなく，一側腎動脈狭窄でもラットで は高血圧の扢こるとを観察した，この高血圧 では, 対側腎に fibrinoid arteriolar necrosisな どの悪性高血圧に特微的に強い血管病変が生ず るが，狭窄腎には組織学的な変化がみられず, 尿毒症の所見も得られなかった。 対側腎は上昇 した血圧の影響を受けるが，狭窄腎は狭窄があ るために高血圧から保護されていると説明され ている。この場合は, 排泄障害のないこと, 体 液性因子が関与するならば狭窄腎もその作用を
受けることが考光られるが，それが認められな いことなどの理由から，この観察は血管病変の 成因に関する高血圧説を支持する有力な根拠を 与えた。しかしながら，狭窄が高血圧の影響を 確実にプロテクトするか否かについては, 今日 でもなお確証がない5．

Byrom と Dodson ${ }^{32)}$ はラットの大動脈内へ Ringer 液を急速に注入することにより，23匹中 10匹に acute necrotizing arteritis が生ずること を観察したが，病変は腎に限局していたとい 5. Masson ら ${ }^{33)}$ の成績もこれを支持している が，これに否定的な報告もある ${ }^{34)}$. 昇圧物質の 投与による血管病変の作製実験では, vasopres$\sin ^{35)}$, tyramine ${ }^{36)}$, methoxamine ${ }^{37)}$ による血压 の上昇と, 動脈の壊死性病変が観察されている. しかし, その組織像は悪性高血圧の特徴とされ る fibrinoid necrosis とは異なるとする意見も ある ${ }^{38)}$.

以上のように, 機械的因子, あるいは昇圧物 質投与による血管内压上昇に伴って, fibrinoid necrosis ないし類似の血管病変がおこりらるこ とは，悪性高血压にみられる血管病変の成因に 血圧上昇がきわめて重要な役割を演ずることを 示唆している.

これに反し，Kincaid-Smith ら ${ }^{6)}$ は前述した ごとく, 良性高血圧と悪性高血圧は血圧の差に もとづくものではないと述べている，Perera ${ }^{39)}$ は 6 例の悪性高血圧に拈いて, 経過中に血圧が 正常化したにもかかわらず, 眼底の乳頭浮腫お よび網膜症が消失しなかったことを観察した。 また剖検された 2 例に执いて動脈の壊死性病変 を認め，これを“'hypertensive disease without hypertension”として報告している。また Sommers ら ${ }^{40)}$ の腎生検材料について検討した 成績は, fibrinoid necrosis が良性の高血圧にも 認められ，必ずしも拡張期圧に相関して生ずる ものではないことを示している。

Flemming ${ }^{41)}$ の一側腎摘出後残った腎動脈に 狭窄を施こして作製した高血圧家鬼での実験成 績は, fibrinoid necrosis の成因に高血圧以外の 因子の関与を否定できないことを示唆している 点で興味深い.すなわち, これらの家鬼の中に 
は，尿毒症で死亡するものがあるが，そのなか に典型的な動脈病変が生じた。ささらに生さ残っ た家鬼の狭窄腎を除去して無腎にすると，この 場合には血管病変が認められなかった。 高血圧 以外の因子を否定できないとする報告は他にも いくつか存在する ${ }^{42)}$.

以上の成績が示すように, 悪性高血圧の成因 に高血圧の程度と持続が重要な因子として関与 していることは確かと考兄られるが，それ以外 の要因が血管病変の発生に関与している可能性 を完全に否定できない.

さらに Pickering の学説が触れていない昇圧 機序, すなわち拡張期血压をさらに増加させる 機序に検討を加えるとき, 腎臓の役割を考察す ることが必要となる。

\section{2. 腎障害およびこれに関連した体液性, 代 謝性因子}

悪性高血圧は，もし脳卒中，心不全などによ る死亡を免れる場合は, その終未像は腎障害一尿毒症である。これは悪性高血圧に抢いても， 良性高血圧と同様に，腎の細小動脈がもっとも 強く, もっとも高頻度に障害されるため ${ }^{114) 11)}$ 考えられる。 これによって, ネフロンが進行性 に破壊されることが，腎不全が急速に出現する 理由とされる ${ }^{11)}$. Retinopathy, 脳浮腫ととも に，Fishberg() はとくに腎に沶ける arteriolar necrosis と endoarteritis を本症に特徵的な所見 としてあげている。

悪性高血圧の基礎疾患別頻度を Kincaid-Smith $5^{6)}$ の124例についてみると, 本態性高血圧 52 例がもっとも多いが, 種々の腎疾患に起因す る悪性高血圧の合計は60例（48\%）である。こ れは，2次性高血圧の中で腎性高血圧の頻度の 高いことを反映しているためとも考学られる が，大動脈縮窄症では本症の報告がないことを 考えると，1次的にしろ 2 次的にしろ腎障害と 覀性高血圧の関係の深いことを示唆している.

悪性高血圧の成因は形態学的变化の解釈を中 心に進展してきた感がある.Volhard とFahr1) の腎病変の混合型 (Kombinationsform) は硬化 性病変に炎症が加わった病理像との解釈から, 良性腎硬化とは別の entity に属する疾患と考
えられた。 これに対し Löhlein ${ }^{43)}$ は，炎症性の 病変の存在を否定し悪性腎硬化は良性腎硬化と 同じように硬化性の病変であるとし，その原因 を虚血に求め vasculäre Schrumpfniere といら 表現を用いた。 Jores ${ }^{44)}$ ，Fishberg ${ }^{45)}$ らも同様に 炎症の存在を否定した。そ後, Volhard ${ }^{46)}$ は 悪性高血圧の特徵的病变を炎症ではなく血管攣 縮で説明しょうとしたが，Fahr ${ }^{47)}$ は增殖性病 変は虚血のみでは説明できないとし，体液性因 子を含めた毒素によるものと考光た。 Herxheimer も炎症ではないが, 動脈硬化以外の要素の 関与を考えた ${ }^{48)}$.

1960年以降 renin-angiotensin-aldosterone 系 （R-A-A 系）が確立されてから，悪性高血圧の 成因と病態に関する研究は一段と進展した。

R-A-A 系については別に記述したことがあるの で9749，重複を避けるが，もっとも注目される のは, Goldblatt 型高血圧と悪性高血圧の 場合 である。

ヒトの悪性高血圧では, 腎血管性高血圧と同 様に血漿レニン活性 (PRA) とアルドステロン 分泌率 (ASR) がしばしば高值を示すことはよ

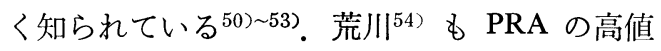
は悪性高血圧の診断根拠の 1 つになると述べて いる。 アルドステロン自体には, 昇圧活性がな く, PRAが低值を示す Conn 症候群では, 本症 がきわめて起こりにくいとされていること列, 悪性高血圧の臨床所見に先立って, PRA の上 昇がみられること年などから，これが本症の成 因に関与している可能性が考兄られた。しかし ながら，Conn 症候群でも悪性高血圧が抏こ

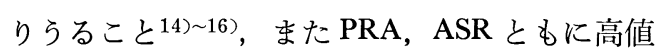
を示す二次性アルドステロン症で, 浮腫性疾 患, Bartter 症候群, 塩分制限時などの場合は, 高血圧も血管障害もみられないことも明かにさ れている。 したがって, 悪性高血圧の原因を一 元的に R-A-A 系に結びつけることは困難のよ らに思える。近年 McAllister $5^{56)}$ は 22 例の悪 性高血圧で, PRA, ASR ともに正常な 3 例を 示し,さらに PRA が高值を示す症例は $36 \%$ に すぎないと報告している。 また PRA が高い症 例でも，降圧療法によって大部分の例が正常 
化することから，本症に打ける PRA の上昇 は，血管障害と密接に関連した機序で 2 次的に おこる可能性を指摘している，すなわち，悪性 高血圧にみられる PRA の上昇は，腎に和ける 血管の閉塞性病変による結果現象であるとする 解釈である。大部分の系球体が硝子化した硬化 腎で，残存する細動脈壁に JG 顆粒を有する中 膜の類上皮細胞が著增し, renin 含量も增して いるとの報告 ${ }^{57)}$ は，これを支持するように思光 る.

しかしながら，すでに人工透折を要するに至 った悪性高血圧のなかに，荒㾱腎が残存する限 り PRA が上昇し，透折や降圧剂による血圧の コントロールが困難で, 血管病変が増悪して, 予後のきわめて悪い場合がある。このような場 合に腎摘出を行ならと，血圧のコントロールが よくなることが知られている ${ }^{58799) . ~ こ の こ と ~}$ は，PRA の上昇ないしは病態腎の有無それ自 体が，悪性高血圧の病態に強くかかわっている ことを示している.

これに対応すると考えられる実験が, Winternitz ら ${ }^{60)}$ によってなされている。両腎摘を行 なった犬は, 血圧上昇も強くなく, 血管病変も きわめてまれにみるにすぎない。これに反し， 両側腎動脈を完全に結禁した場合，著しい血圧 上昇とともに 組織の強い浮腫, 出血, 血管の 強い壊死が生ずる，彼らはこのような病変が変 性した腎組織から遊離する物質 (angiotoxic agents）に由来すると考えた。両側腎動脈に排 泄機能が失なわれる程度の強い狭窄を施した実 験でもほ汸同様の変化がみられる ${ }^{61)}$.Winternitz $ら^{60)}$ はさらに腎摘動物に上述の壊死腎のみなら ず正常腎の抽出液を投与することによって，同 様の結果を得, 腎由来の体液性あるいは代謝性 因子の存在を示している. Nairn ら ${ }^{62)}$ も同様の 方法で家鬼について実験を行ない，胸腔，腹 腔に滲出液が生ずることを報告した。Asscher と Anson ${ }^{63)}$, Giese ${ }^{61) 64)}$ も腎抽出液中に 昇圧, 血管病変の発生, 血管からの plasma leak の䒕 進をきたす性質が存することを述べている，同 様に著者ら ${ }^{65)}$ は昇圧活性の高い腎からの抽出液 は肺水腫を高率に起こすことを報告した。
Giese $^{5)}$ はさらに, 腎摘動物に renin, angiotensin II の大量投与を行なっても，前述の腎抽出液に よって生起されたと同じ病変（細動脈の壊死性 病変, 大量の胸腔内扥よび腹腔内滲出液の出 現）が生ずることから，腎抽出液に含まれる体 液性因子は R-A系である可能性が大きいとして いる，教室の小野山ら ${ }^{66)}$ はこのような体液性因 子が，腎皮質のライソン゙ーム分画に存すること を明らかにした。この因子の精製を試みた Cuthbert ら ${ }^{67} は$ は, 得られた精製物がほぼ renin と 同一の性質を備えていると報告している。その 他，昇圧活性を有しない腎由来の血管障害性因 子の存在する可能性が報告されている

これらの腎皮質に由来する体液性因子が血管透 過性の元進，あるいは昇圧との関係などで，い かなる機序によって血管障害を発生せしめるか の研究は, 今後の大きな課題といえる.

一方，正常腎には高血压の発症に拮抗する働 きのあることが Fasciolo（1938）の指摘以来知 られている。 その機能の本態は，今日未だ十分 明らかでないが, Muirhead 一派 ${ }^{11)}$ はその機能 は腎髄質にあると述べ，Lee ら ${ }^{72}$ はこの因子が prostaglandin $\mathrm{E}_{2}$ であるとしている。これまで に述べてきたように，悪性高血圧の病因には腎 蔵がきわめて重要な役割をもつと考えられるの で, その機能の解明は, 高血圧学に扣ける今後 の重要な問題である.

\section{3. 乳頭浮腫の成因}

悪性高血圧の末期には，きわめて高頻度に髄 圧の上昇が認められ，その蛋白含量が増加し ${ }^{19}$, 脳浮腫も同時飞認められる ${ }^{73)}$ ので, Fishberg4) は乳頭浮腫の原因を高血圧による脳浮腫と䯣圧 の上昇に求めた。 Pickering11) も同様に視神経 鞘に添った髄圧の上昇による中心網膜静脈圧の 上昇とリンパ流の停滞をその成因と考えた。

一方, Byrom ${ }^{74)}$ 《悪性高血圧の末期にみる高 血圧性脳症についての実験で, 脳皮質の水分含 量が増し，さらに血管から血液成分が散在性に 汇出することを報告した。類似の実験で，著者 $ら^{75)}$ も電顕を用いて検討を加えたが，本症の特 徵は脳の浮腫像であることを確認した。しかも このような状態で, 細静脈から ferritin 粒子が 
pinocytosis により血管外へ運び出される透過性 の立進像を得ている ${ }^{76)}$. この所見は, 本症の末 期に髄圧が上昇し, 蛋白含量が増加するのは, 脳の血管透過性の克進に由来するものであろら ことを示唆している. 最近 Giacomelli ら ${ }^{77)}$ も 本症の網膜の血管透過性に検討を加光, 局在性 に microcirculation の障害を示す所見を報告し ている.

他方, 乳頭浮腫は 1 側のみに認めることがあ り,さらに髄圧の上昇を伴なわない本症も存す る ${ }^{19)}$ こから，現在な拈との成因は不明と考克 るもの22) もある.

\section{4. 高血圧性血管病変のなり立ち}

この問題については, Giese ${ }^{5)}$ の優れた総説が あるので，最近の電顕を用いた研究について簡 単に触れたい，本症の特徵的所見と考兄られる 細胞性内膜増殖 (cellular intimal hyperplasia) において, 内膜に增殖してくる細胞型は光顕し ベルで議論の多いところである。電顕観察の結 果, fibrocyte ${ }^{78)}$ や血液由来の単核細胞 ${ }^{79)}$ の存在 を記載したものもあるが，多くは中膜に由来す ると思われる平滑筋細胞が内膜へ侵入したもの とする報告78)80) 82) が大部分である。しかし， 血管内皮細胞が transformation を掞こし, 平 滑筋細胞となった可能性は否定できない,83).

Fibrinoid necrosis の病変の中には幅 $300 \AA$ の規則的な周期性を有する結晶構造がみられ， pure fibrin の電顕所見の特性と良く一致する とされている81)84) 86).

さらに動脈壁の血管透過性の異常について, 各種の tracerを用いた検索結果が報告され ている，病変の程度に応じて，質の異なった透 過性の无進機序が明らかになりつつある。内皮 細胞間吵の完全な離開87) 89), tight junction の 開大 ${ }^{90)}$, gap junction の拡大 ${ }^{91)}$, transmembranous transport の充進 ${ }^{88)}$, pinocytosis の艺

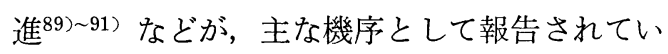
る。血管障害のいまだ顕著でない時期に括い て，血管壁の生理的な透過性機序である small pore system ${ }^{91)}$, large pore system ${ }^{89) 91)} の$ 立進が すでに認められることは，血管病変の成因を考 える上で，きわめて興味深いことと考える。

\section{むすび}

悪性高血圧の成因を，その診断基準の検討に 基づいて，主として高血圧と腎障害，およびそ れに関連し太体液性因子の関与について論じ た。ささらに乳頭浮腫および血管障害のなり立ち について, 血管透過性立進の問題を簡単に触れ た。腎由来の体液性因子が昇圧, 血管透過性亢 進, その他のいかなる機序を介して悪性高血圧 の血管障害を生ぜしめるかという問題が，本症 の成因を解明する上でのもっとも緊急なテーマ であることを指摘した。

\section{文 献}

1) Volhard, F. und T. Fahr: Die Brightsche Nierenkrankheit, Klinik. Pathologie und Atlas, Springer, Berlin, 1914.

2) Keith, N.M. et al.: Arch. Int. Med., 41; 141, 1928.

3) Allen, A.C.: The Kidney, Medical and Surgical Diseases, 2nd. Ed., Grune and Stratton, New York, 1962.

4) Fishberg, A.M.: Hypertension and Nephritis, Lea and Febiger, Philadelphia, 1954.

5) Giese, J.: The Pathogenesis of Hypertensive Vascular Disease, Munksgaard, Copenhagen, 1966.

6) Kincaid-Smith, P. et al.: Quart. J. Med. N.S., 27; 117, 1958.

7) Milliez, P. et al.: In Essential Hypertension: An International Symoposium, Berne, June 7th-10th, 1960, Edited by Bock, K.D. and P.T. Cottier, p.214, Springer, Berlin.

8）藤井潤, 池田正雄 : 最新医学, 22；936，1967.

9）尾前照雄: 高血圧, 「病気の生化学」第 2 巻, 主要症状 II, 中山書店, 1965.

10）尾前照雄, 他: 綜合臨床, 14；1903，1965.

11) Pickering, G.W.: High Blood Pressure, Churchill, London, 1968.

12) Horrobin, D.F.: Lancet, 2; 1008, 1969.

13) Conn, J.W. et al.: Amer. J. Surg., 107; 159, 1964.

14）田仲謙次郎, 他：日本臨床, 29；918, 1971.

15) Kaplan, N.M. et al.: New Engl. J. Med., 269; 1282, 1963.

16) Brown, J. J. et al.: J. Endocr., 33; 279, 1965.

17) Page, I.H.: Ann. Int. Med., 12; 978. 1939. 
18) Ellis, A.: Lancet, 1; 977, 1938.

19) Schottstaedt, M.F. and M. Sokolow: Amer. Heart J., 45; 331, 1953.

20) Brust, A.A. et al.: J.A.M.A. 166; 640, 1958.

21) Keith, N.M. et al.: Amer. J. med. Sci., 197; 332, 1939.

22) Gifford, R.W.Jr.: Bull. N.Y. Acad. Med., 45; 922, 1969.

23) Keith, N.M. and H.P. Wagener: Arch. Int. Med., 87; 25, 1951.

24) Goldring, W. and H. Chasis: Hypertension and Hypertensive Disease, Commonwealth Fund, New York, 1944.

25) Perera, G.A.: J. Chron, Dis., 1; 472, 1955.

26) Heptinstall, R. H.: Brit. Heart J., 16; 133, 1954.

27) Goldblatt, H. et al.: J. exp. Med., 59; 347 , 1934.

28) Goldblatt, H.: J. exp. Med., 67; 809, 1938.

29) Wilson, C. and G.W. Pickering: Clin. Sci., 3; 343, 1938.

30) Allison, P.R. et al.: Clin. Sci., 33; 39, 1967.

31) Wilson, C. and F.B. Byrom: Lancet, 1; 136, 1939.

32) Byrom, F.B. and L.F. Dodson: J. Path. Bact., 60; 357, 1948.

33) Masson, G.M.C. et al.: Rev. Canad. Biol., 10; 309, 1951.

34) Schaffenburg, C. and H. Goldblatt: Proc. Soc. exp. Biol. (N.Y.), 96; 421, 1957.

35) Byrom, F.B.: J. Path. Bact., 45; 1, 1937.

36) Duff, G.L. et al.: Proc. Soc. exp. Biol. (N. Y.), 41; 295, 1939.

37) Giese, J.; Acta path. microbiol. scand., 62; 481, 1964.

38) Gardner, D.L.: Brit. J. exp. Path., 43; 213, 1962.

39) Perera, G.A.: Circulation, 10; 28. 1954.

40) Sommers, S.C. et al.: Amer. J. Path., 34; 685, 1958.

41) Fleming, H.A.: J. Path. Bact., 65; 441, 1953.

42) Campbell, W. G. and C. A. Santos-Buch: Amer. J. Path., 35; 439, 1959. i.b.i.d., 35; 769, 1959. i.b.i.d., 43; 131. 1963.

43) Löhlein, M.: Med. Klin., 12; 741, 872, 1042, 1916. i.b.i.d., 14; 136, 1918.

44) Jores, L.: Virchows Arch. path. Anat., 221; 14, 1916.

45) Fishberg, A.M.: Arch. Int. Med., 35; 650,
1925.

46) Volhard, F.: Verhandl. deut. Gesellsch. inn. Med., 35; 134, 1923.

47) Fahr, T.: Virchows Arch. path. Anat., 226; 119, 1919.

48) Shapiro, P.F.: Arch. Int. Med., 48; 199, 1931.

49）尾前照雄, 他: 最新医学, 19；2660, 1964.

50) Creditor, M.C. and U.K. Loschky: Amer. J. Med., 43; 371, 1967.

51) Del Greco, F. et al.: Medicine, 46; 475, 1967.

52) Weinberger, M.H. et al.: J. Clin. Endocr., 28; 359, 1969.

53) Laragh, J.H. et al.: J. Clin. Invest., 39; 1091, 1960.

34）荒川規矩男, 他 : 内科, 24；610., 1969.

55) Laragh, J.H. et al.: Circ. Res., 18 Suppl. 1; 158, 1966.

56) McAllister, R.G. et al.: Circ. Res., 28/29, Suppl. 2; 160, 1971.

57) Faarup, P.F. et al.: Acta path. microbiol. scand., Section A. 78; 674, 1970.

58) Vertes, V. et al.: New Engl. J. Med., 280; 978, 1969.

59) Brown, J.J. et al.: Nephron, 6; 329, 1969,

60) Winternitz, M.C. et al.: Yale J. Biol. Med., 12; 623, 1939-40.

61) Giese, J. Acta path. microbiol. scand., 56; 399, 1962.

62) Nairn, R.C. et al.: J. Path. Bact., 71; 155, 1956.

63) Asscher, A.W. and S.G. Anson: Nature, 198; 1097, 1963.

64) Giese, J.: Acta path. microbiol. scand., 59; 417, 1963.

65) Omae, T. et al.: Amer. Heart J., 75; 76, 1968.

66）小野山薰, 他：脈管学, 11；163，1971.

67) Cuthbert, M.F. and W.S. Peart: Clin. Sci., 38; 309, 1970.

58) Nakao, K. et al.: Jap. Circ. J., 30; 539, 1966.

69）小野山薰, 他：第 15 回日本腎学会総会発表, 1972.

70）西森一正, 他：脈管学, 12；432，1972.

71) Muirhead,E.E. et al.: J. Lab. Clin. Med., 54; 930, 1959.

72) Lee, J.B. et al.: J. Clin. Invest., 45; 1036, 1966. 
$4: 28$

73) Pickering, G.W.: Circulation, 6; 599, 1952.

74) Byrom, F.B.: Lancet, 2; 201, 1954.

75) Eto, T. et al.: Arch. histol. jap., 33; 133, 1971.

76）江藤㻆尚：福医誌, 63；272，1972.

77) Giacomelli, F. et al.: Amer. J. Path., 68; 81, 1972.

78) McGee, W.G. and C.T. Ashworth: Amer. J. Path., 43; 273, 1963,

79) Still, W.J.S.: Lab. Invest., 19; 84, 1968.

80) Spiro, D. et al.: Amer. J. Path., 47; 19, 1965.

81) Aikawa, M. and S. Koletsky: Amer. J. Path., 61; 293, 1970.

82）尾前照雄, 他：日本臨床, 30；1396, 1972.

83) Hatt, P.Y.: In "Hypertension-72" Edited by
血液 と脈管第 4 巻第 1 号

Genest, J. and E. Koiw, p. 196, Springer Berlin, 1972.

84) Wiener, J. et al.: Amer. J. Path., 47; 457, 1965.

85) Ooneda, G. et al.: Angiology, 16; 8, 1965.

86) Hüttner, I. et al.: Exp. Mol. Path., 9; 309, 1968.

87) Wiener, J. et al.: Amer. J. Path., 54; 187 1969.

88) Suzuki, K. et al.: Exp. Mol. Path., 15; 198, 1971.

89）江藤片尚, 他：脈管学, 12；195，1972.

90) Giacomelli, F. et al.: Amer. J. Path. 59: 133, 1970.

81) Hüttner, I. et al.: Amer. J. Path., 61; 395, 1970. 